\title{
KELIMPAHAN DAN KEANEKARAGAMAN GASTROPODA PADA ZONA INTERTIDAL DI PULAU BANGKA BAGIAN TIMUR
}

\author{
Okto Supratman, Arthur M Farhaby, Jemi Ferizal \\ Jurusan Manajemen Sumberdaya Perairan, Universitas Bangka Belitung \\ oktosupratman@gmail.com
}

Received March 2018, Accepted April 2018

\begin{abstract}
ABSTRAK
Kerusakan lingkungan dari aktifitas antropogenik akan menyebabkan terjadinya penurunan kualitas air, yang kemudian berdampak kepada organisme akuatik termasuk Gastropoda. Hal ini sehingga perlu dilakukan suatu kajian tentang keanekaragaman dan kelimpahan gastropoda di Pulau Bangka Bagian Timur. Penelitian ini dilakukan pada bulan Juni sampai Desember 2017. Lokasi penelitian dibagi menjadi 6 stasiun. Pengambilan data gastropoda menggunakan kuadrat ukuran $50 \mathrm{~cm}$ x 50 $\mathrm{cm}$, yang dilakukan dengan cara pengambilan langsung gastropoda menggunakan tangan, kemudian di identifikasi di Laboratorium. Hasil Penelitian ini ditemukan sebanyak 12 spesies gastropoda dari 8 famili. Famili yang ditemukan yaitu Cerithideidae (2 spesies), Cerithiidae (1 spesies), Cirridae (1 spesies), Nassariidae (2 spesies), Neritidae (2 spesies), Planaxidae (1 spesies), Muricidae (1 Spesies) dan Costellariidae (2 Spesies). Kelimpahan gastropoda yang tertinggi yaitu spesies Certhidea cingulata dengan kelimpahan rata-rata $124,54 \mathrm{ind} / \mathrm{m} 2$. Adapun nilai indeks keanekaragaman gastropoda di Pulau Bangka bagian timur dikategorikan kecil, hal ini diduga disebabkan oleh kerusakan habitat akibat dari aktifitas pertambangan di laut.
\end{abstract}

Kata Kunci : Gastropoda, Keanekaragaman, Kelimpahan, Zona Intertidal

\begin{abstract}
Environmental damage from anthropogenic activity will lead to a decrease in water quality, which then affects aquatic organisms including Gastropoda. So it is necessary to do a study of diversity and abundance of gastropods in East Bangka Island. The study was conducted from June to December 2017. The research locations were divided into 6 stations. Data collection of gastropods using squares of size $50 \mathrm{~cm} \times 50 \mathrm{~cm}$, performed by direct gastropod removal by hand, then identified in Water Resource Management Laboratory. The results of this study found 12 species of gastropods from 8 families. The families found are Cerithideidae (2 species), Cerithiidae (1 species), Cirridae (1 species), Nassariidae (2
\end{abstract}


species), Neritidae (2 species), Planaxidae (1 species), Muricidae (1 Species) and Costellariidae (2 Species). The highest abundance of gastropods is Certhidea cingulata species with an average abundance of 124.54 ind $/ \mathrm{m}^{2}$. The value of diversity index of gastropod in the eastern part of the island of Bangka categorized small, it is thought to be caused by loss of habitat as a result of mining activities at sea.

Keywords : Gastropods, Diversity, Abundance, Intertidal Zone

\section{PENDAHULUAN}

Zona intertidal atau zona pasang surut adalah bagian dari tepi pantai yang tergenang air pada waktu air pasang (menjadi perairan) namun kering pada waktu air surut (menjadi daratan), (Suwignyo et al, 2005). Hampir semua organisme yang hidup di wilayah intertidal ini adalah organisme bahari (Nybakken, 1988). Salah satu habitat organisme di daerah intertidal ini adalah jenis Moluscca. Moluscca adalah hewan lunak yang memiliki tubuh simetri bilateral, tertutup mantel yang menghasilkan cangkang dan mempunyai kaki ventral, (Suwignyo et al, 2005). Diantara 8 (delapan) kelas molusca, yang paling umum ditemui didaerah intertidal yaitu kelas gastropoda.

Gastropoda umumnya ditemukan di substrat berpasir, berbatu dan berlumpur, selain itu juga faktor lingkungan seperti cahaya, kecerahan, kekeruhan, suhu, salinitas, dan $\mathrm{pH}$ juga ikut mempengaruhi perkembangbiakannya. Gastropoda merupakan salah satu kelompok terpenting dalam ekosistem perairan sehubungan dengan peranannya sebagai organisme kunci dalam jaring makanan. Selain itu tingkat keanekaragaman yang terdapat di lingkungan perairan dapat digunakan sebagai indikator pencemaran. Dengan adanya kelompok hewan tersebut yang hidup menetap (sesile) dan memiliki daya adaptasi terhadap lingkungan yang cukup baik.

Seiring dengan pemanfaatan sumberdaya alam potensial untuk memenuhi kebutuhan manusia, maka wilayah zona intertidal juga dilakukan ekplorasi, seperti kegiatan ekplorasi sumberdaya perikanan, sumberdaya energy dan tambang, dan pariwisata. Banyaknya kegiatan yang dilakukan pada zona ini merupakan ancaman bagi beberapa biota yang hidup di zona ini khususnya jenis gastropod. Seperti yang diketahui bahwa wilayah intertidal pesisir pulau Bangka bagian timur telah banyak aktivitas-aktivitas eksplorasi sumberdaya perikanan seperti penangkapan jenis siput dan kerang kerangan, aktivitas pertambangan Timah, dan aktivitas pariwisata yang dapat menyebabkan habitat dan factor lingkungan pembatas bagi kehidupan gastropoda terganggu. Hasil dari kegiatan pemanfaatan sumberdaya alam tersebut tentunya dapat merubah ekosistem sebelumnya, diantaranya ialah perubahan struktur habitat bagi biota perairan. Namun Saat ini data dan informasi tentang keanekaragaman dan kelimpahan gastropoda sangat minim sekali. Kondisi ini sehingga perlu dilakukan penelitian tentang keanekaragaman 
dan kelimpahan Gastropoda di Zona Intertidal di Pulau Bangka Bagian Timur.

\section{MATERI DAN METODE}

\section{Waktu dan Lokasi Penelitian}

Penelitian ini dilaksanakan pada bulan Juni sampai Desember 2017. Pengambilan sampel di lapangan meliputi beberapa wilayah di daerah intertidal Pulau Bangka Bagian Timur yaitu di Kabupaten Bangka, Kabupaten Bangka Tengah dan Kota Pangkal Pinang. Sampel yang diambil terdiri dari 6 stasiun yang meliputi pantai Tanjung Gunung (Stasiun 1), Pantai Batu Belubang (Stasiun 2), Pantai Tanjung Bunga (Stasiun 3), Pantai Jembatan Emas (Stasiun 4), Pantai Pukan (Stasiun 5) dan Pantai Air Anyir (Stasiun 6). Lokasi penelitian secara rinci disajikan pada Gambar 1. Deskripsi Karakteristik disetiap stasiun terdapat pada Tabel 1.
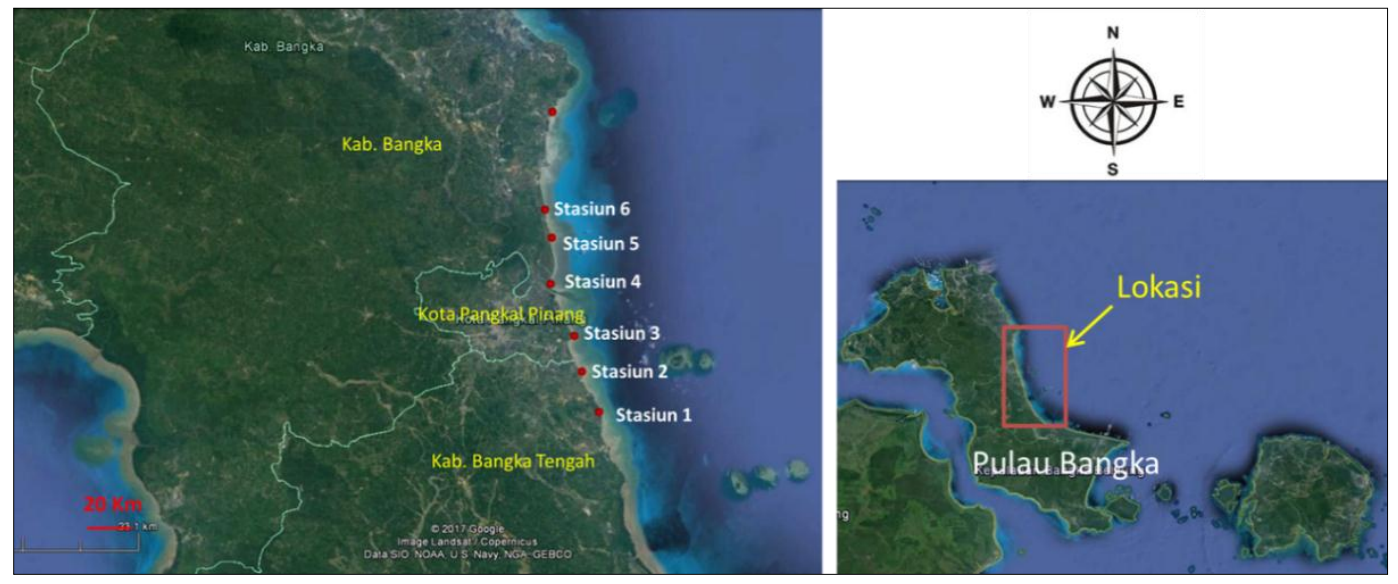

Gambar 1. Lokasi Penelitian (Sumber : Google earth)

Tabel 1. Karakteristik Lokasi Pengambilan Sampel

\begin{tabular}{llrlll}
\hline Stasiun & Lokasi & \multicolumn{2}{l}{ Koordinate } & Karakteristik \\
\hline 1 & Pantai & Batu & $\mathrm{S} 02^{\circ}$ & $12^{\prime}$ & Mangrove dan aktivitas \\
& Gunung & $00,4^{\prime \prime}$ & & pertambangan timah laut \\
& & $\mathrm{E} 106^{\circ}$ & $12^{\prime}$ & & \\
& & $14,3^{\prime \prime}$ & & & \\
2 & Pantai & $\mathrm{S} 02^{\circ}$ & $09^{\prime}$ & Mangrove, & berlumpur \\
& Betumpang & $49,3^{\prime \prime}$ & & dan & aktivitas \\
& & $\mathrm{E} 106^{\circ}$ & $11^{\prime}$ & pertambangan timah laut \\
& & $18,4^{\prime \prime}$ & & & \\
& & $\mathrm{S} 02^{\circ}$ & $07^{\prime}$ & Mangrove & dan pantai \\
& Tanjung Bunga & $55,0^{\prime \prime}$ & & berbatu & \\
& & $\mathrm{E} 106^{\circ}$ & $10^{\prime}$ & & \\
\hline
\end{tabular}




\begin{tabular}{|c|c|c|c|c|}
\hline & & $54,1^{\prime \prime}$ & & \\
\hline 4 & $\begin{array}{l}\text { Pantai Jembatan } \\
\text { Emas }\end{array}$ & $\begin{array}{l}S \quad 02^{\circ} \\
08,1^{\prime \prime} \\
E \quad 106^{\circ} \\
38,0^{\prime \prime}\end{array}$ & $\begin{array}{l}05^{\prime} \\
09^{\prime}\end{array}$ & $\begin{array}{l}\text { Aliran sungai dan pantai } \\
\text { berpasir }\end{array}$ \\
\hline 5 & Pantai Pukan & $\begin{array}{l}S \quad 02^{\circ} \\
39,5^{\prime \prime} \\
E \quad 106^{\circ} \\
41,7^{\prime \prime}\end{array}$ & $\begin{array}{l}02^{\prime} \\
09^{\prime}\end{array}$ & $\begin{array}{l}\text { Pantai } \quad \text { berpasir } \\
\text { aktivitas pariwisata }\end{array}$ \\
\hline 6 & Pantai air anyir & $\begin{array}{l}S \quad 02^{\circ} \\
09,5^{\prime \prime} \\
E \quad 106^{\circ} \\
20,0^{\prime \prime}\end{array}$ & $\begin{array}{l}01^{\prime} \\
09^{\prime}\end{array}$ & $\begin{array}{l}\text { Pantai berpasir } \\
\text { aktivitas pariwisata }\end{array}$ \\
\hline
\end{tabular}

\section{Pengambilan Sampel di Lapangan}

Pengambilan sampel gastropoda dilakukan menggunakan kuadrat berukuran $50 \times 50 \mathrm{~cm}$. Penentuan plot kuadrat disetiap stasiun penelitian dilakukan secara random di zona intertidal, pemasangannya dilakukan dari mulai pinggir pantai ka arah laut. Pengambilan sampel gastropoda dilakukan dengan dua cara yaitu 1) Pengambilan sampel secara langsung menggunakan tangan untuk epifauna dan 2) Pengambilan substrat dengan kedalaman \pm 15 untuk infauna (Irma dan Sofyatuddin, 2012). Sample gastropoda setelah diambil, kemudian di ayak menggunakan penyaring sehingga sampel terpisah dengan lumpur dan tanah. Setelah itu sampel dimasukan kedalam plastik sampel, kemudian diawetkan menggunakan alkohol $70 \%$ untuk di identifikasi di laboratorium. Identifikasi spesies dari gastropoda dilakukan dengan cara mencocokan morfologi spesies yang ditemukan di buku identifikasi. Identifikasi gastropoda berdasarkan buku identifikasi Dharma, (1998), Poutiers (1998).

Selain pengambilan sampel Gastropoda dilakukan pengukuran parameter lingkungan yang meliputi suhu, salinitas, $\mathrm{pH}$, Kedalaman, Kecerahan, Tekstur substrat dan Bahan Organik total. Parameter lingkungan diukur di setiap stasiun minimal 3 kali ulangan. Pengambilan substrat dilakukan menggunakan pipa paralon berdiameter $\pm 10 \mathrm{~cm}$, dengan cara menancapkan paralon ke dasar perairan sedalam $\pm 20 \mathrm{~cm}$. Sampel substrat di dalam paralon diambil sebanyak \pm 500 gram, kemudian dimasukan ke dalam kertas sampel untuk dianalisis bahan organik total yang dilakukan di laboratorium. 


\section{Analisis Data}

\section{Kepadatan Spesies}

Kepadatan spesies berdasarkan jumlah individu yang ditemukan di setiap kuadrat $0,5 \times 0,5$ meter. Perhitungan kepadatan spesies gastropoda dan bivalvia menggunakan rumus Krebs (1998).

$$
d=\frac{x}{z\left(m^{2}\right)}
$$

Dimana : $d=$ Kepadatan, $x=$ jumlah individu dan $z=$ luas area daerah sampel.

\section{Indeks Keanekaragaman}

Indeks Keanekaragaman lamun di hitung dengan menggunakan persamaan Indeks Shannon-Wiener berikut ini (Brower et al, 1990).

$$
H^{\prime}=-\sum_{i=l}^{n} p i \ln p i
$$

Dimana:

$\mathrm{Pi}=\sum \mathrm{ni} / \mathrm{N}$

$\mathrm{H} \quad$ : Indeks Keragaman Shannon-Wiener

$\mathrm{Pi} \quad$ : Jumlah individu suatu spesies/jumlah total seluruh spesies

ni : Jumlah individu spesies ke-i

$\mathrm{N}$ : Jumlah total individu

\section{Indeks Keseragaman}

Indeks Keseragaman lamun dihitung dengan menggunakan persamaan berikut ini (Odum, 1971)

$$
e=\frac{H^{\prime}}{\operatorname{Ln} S}
$$

Dimana :

$\mathrm{e}=$ indeks keseragaman;

$\mathrm{H}^{\prime}=$ Indeks Keragaman Shannon-Wiener

$\mathrm{S}=$ Jumlah spesies yang ditemukan.

\section{Indeks Dominansi}

Nilai Dominansi dihitung dengan menggunakan persamaan berikut ini (Odum, 1971)

$$
C=\sum_{i=l}^{S}(P i)^{2}
$$


Dimana :

$\mathrm{C}=$ Indeks dominansi;

$\mathrm{Pi}=$ Perbandingan proporsi individu ke- $\mathrm{i}$

$\mathrm{S}=$ Jumlah jenis yang ditemukan

\section{HASIL DAN PEMBAHASAN}

\section{Parameter lingkungan}

Parameter Lingkungan yang diukur pada penelitian ini yaitu suhu, salinitas, $\mathrm{pH}$, Kedalaman, Kecerahan, Arus dan bahan organik. Adapun hasil pengukuran parameter lingkungan perairan terdapat pada Tabel 2.

Tabel 2. Hasil Pengukuran Rata-rata Parameter Fisika Kimia Perairan di Setiap Stasiun

\begin{tabular}{lllllll}
\hline \multicolumn{7}{c}{ Stasiun } \\
\cline { 2 - 6 } & 1 & 2 & 3 & 4 & 5 & 6 \\
\hline Suhu $\left({ }^{\circ} \mathrm{C}\right)$ & 29,33 & 28,67 & 28,33 & 29,67 & 29,33 & 30,00 \\
Salinitas & 29,00 & 31,00 & 29,33 & 23,33 & 30,33 & 29,67 \\
$\begin{array}{l}\text { Ph } \\
\text { Kedalaman }\end{array}$ & 6,7 & 7,17 & 7,70 & 6,47 & 7,63 & 7,63 \\
$(\mathrm{~cm})$ & 44,00 & 61,00 & 0,00 & 51,67 & 63,33 & 45,00 \\
$\begin{array}{l}\text { Kecerahan } \\
(\%)\end{array}$ & 5,33 & 5,00 & 100 & 71,67 & 100,00 & 100,00 \\
$\begin{array}{l}\text { Arus (m s } \\
\text { Bahan })\end{array}$ & 18,60 & 20,27 & 0,00 & 14,23 & 22,03 & 15,13 \\
$\begin{array}{l}\text { Organik Total } \\
(\%)\end{array}$ & 4,22 & 6,51 & 5,66 & 5,29 & 11,17 & 10,41 \\
\hline
\end{tabular}

Hasil uji anova untuk membandingkan perbedaan parameter lingkungan yang meliputi suhu, salinitas, $\mathrm{pH}$, Kedalaman, Kecerahan, Arus dan Bahan Organik Total adanya perbedaan signifikan ( $p$-value < 0,05 ) di setiap stasiun. Adanya perbedaan parameter lingkungan disetiap stasiun disebabkan oleh perbedaan karakteristik habitat dan permasalahan di lokasi pengambilan data, di Pulau Bangka Bagian Timur (Tabel 1). Hasil penelitian ini menujukan perbedaan karakteristik lokasi akan menyebabkan terjadinya perbedaan parameter lingkungan baik itu parameter fisika kimia dan biologi. Hal ini dapat dilihat pada Tabel 1 pada stasiun 1 dan 2 memiliki kondisi parameter lingkungan yang hampir sama, dibandingkan dengan lokasi lainnya. Stasiun 1 di pantai Batu Gunung dan Stasiun 2 di Pantai Batu Betumpang, daerah ini merupakan daerah penambangan timah dilaut.

Aktifitas pertambangan timah berdasarkan beberapa penelitian sebelumnya dapat menyebabkan terjadinya penurunan kualitas air (Wahyuni et al, 2013; Febrianto dan Kurniawan, 2014; Muslih et al, 2014; Nurtjahya et al, 2017). Penambangan timah laut atau lepas pantai yang 
dilakukan oleh masyarakat dengan mengambil tanah didasar perairan, kemudian sisa pencucian timah dibuang langsung ke perairan, hal ini yang menyababkan terjadinya rendanhya kecerahan perairan (Wahyuni et al, 2013). Selain itu berdasarkan penelitian Febrianto dan Kurniawan, 2014; Nurtjahya et al, 2017 aktifitas penambangan timah dapat meyebabkan terjadinya penurunan Oksigen terlarut (DO) dan $\mathrm{pH}$, selain itu dapat meningkatnya Total suspended solid (TSS), Laju sedimentasi, dan kandungan Logam berat pb. Kondisi ini penurunan kualitas air dampak pertambangan timah, sehingga terjadi kerusakan habitat dan berdampak pada organisme perairan termasuk kelas gastropoda.

\section{Kepadatan Gastropoda}

Total gastropoda yang ditemukan dilokasi penelitian yaitu sebanyak 12 spesies dari 8 famili. Famili yang ditemukan yaitu Cerithideidae (2 spesies), Cerithiidae (1 spesies), Cirridae (1 spesies), Nassariidae (2 spesies), Neritidae ( 2 spesies), Planaxidae (1 spesies), Muricidae (1 Spesies) dan Costellariidae (2 Spesies) (Tabel 3). Hasil pengamatan dilapangan Gastropoda banyak ditemukan dihabitat mangrove, menempel di batu dan pasir yang umumnya bersifat epifauna atau hidup di permukaan substrat. Hal ini sama dengan beberapa penelitian sebelumnya (Irma dan Sofyatuddin, 2012; Silaen et al 2013). Gastropoda yang paling banyak ditemukan yaitu spesies Certhidea cingulata dengan kelimpahan 124,54 ind $\mathrm{m}^{-2}$. Spesies Certhidea cingulata ketika sampling ditemukan mengelompok dan dominan didaerah intertidal. Selain itu spesies ini ditemukan dibeberapa tipe habitat yaitu habitat mangrove, subtrat berlumpur dan substrat berpasir. Hal ini yang menyebabkan spesies ini ditemukan hampir disemua stasiun kecuali di stasiun 3.

Tingginya kepadatan Certhidea cingulata diduga spesies ini memiliki kisaran habitat yang luas dan mampu hidup di berbagai tipe habitat baik itu di ekosistem mangrove, pantai berlumpur sampai berpasir, selain itu spesies ini mampu hidup dikondisi yang tidak stabil seperti di daerah pertambangan. Hal ini dapat dilihat pada hasil penelitian stasiun 2 dengan karakteristik habitat mangrove dan daerah penambangan, $C$. cingulata sangat domninan dibandingkan dengan spesies lainnya ( Tabel 1 dan Tabel 3). Hasil penelitian Silaen et al (2013) diteluk Awur Jepara, $C$. Cingulata sangat dominan didaerah ekosistem mangrove kerapatan yang jarang dan dengan substrat berlumpur. Selain itu spesies $C$. Cingulata mampu hidup dan dominan di kondisi logam berat $\mathrm{Pb}$ melebihi baku mutu pada sedimen (Wahyudi et al, 2015). Aktifitas penambangan timah dapat meningkatnya kandungan logam pb (Wahyuni et al, 2013; Febrianto dan Kurniawan, 2014; Nurtjahya et al, 2017). Kondisi ini yang meyebebkan spesies Certhidea cingulata sangat dominan di beberapa lokasi terutama di daerah lokasi yang tercemar dari penambangan timah dilaut. 
Tabel 3. Kepadatan Gastropoda disetiap stasiun

\begin{tabular}{llllllll}
\hline No Spesies & \multicolumn{2}{l}{ Stasiun $\left(\mathrm{Ind} / \mathrm{m}^{2}\right)$} & & & $\begin{array}{l}\text { Rata-Rata } \\
\left(\mathrm{Ind} / \mathrm{m}^{2}\right)\end{array}$ \\
\cline { 2 - 7 } & 1 & 2 & 3 & 4 & 5 & 6
\end{tabular}

Cerithideidae

Cerithidea

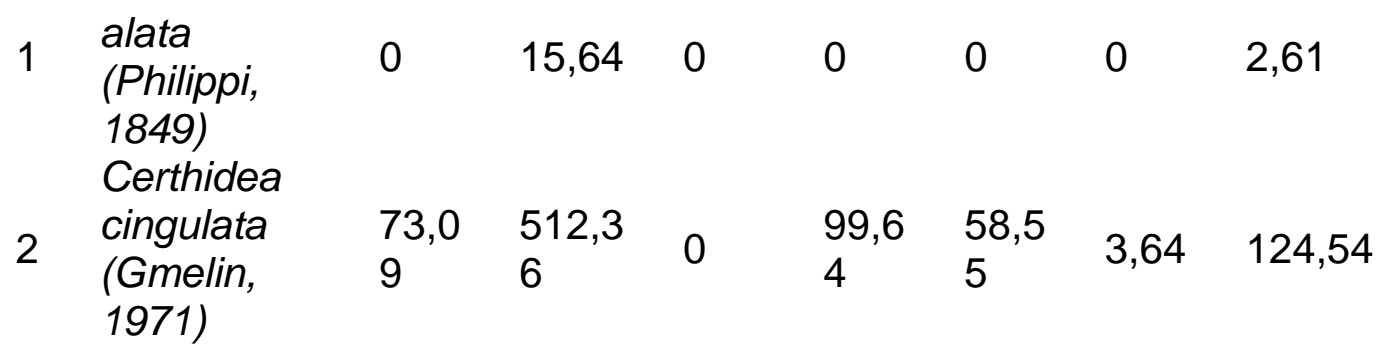

Cerithiidae

Clypeomoru

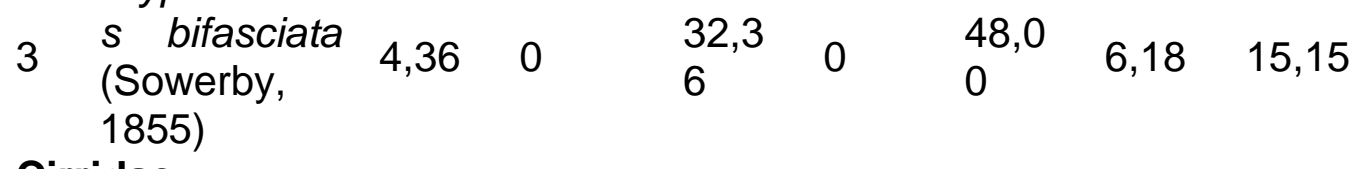

Cirridae

Monodonta

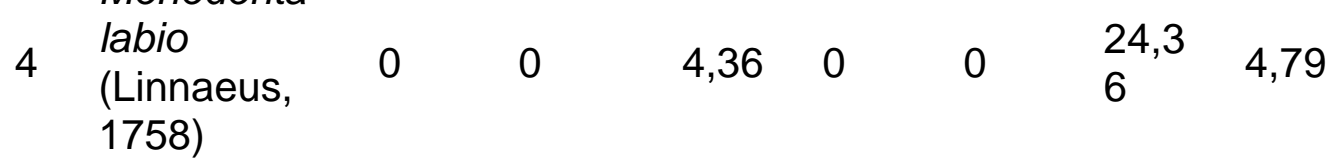

Nassariidae

$5 \begin{aligned} & \begin{array}{l}\text { Nassarius } \\ \text { (zeuxis) } s p\end{array} \\ & \text { Nassarius }\end{aligned}$

Nassarius

acuticostus

(Montrouzier

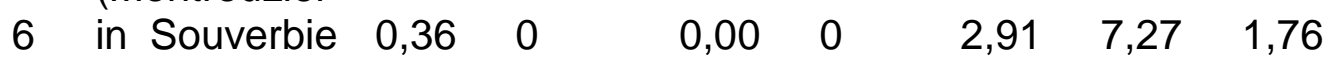
\&

Montrouzier, 1864

Neritidae

Nerita polita

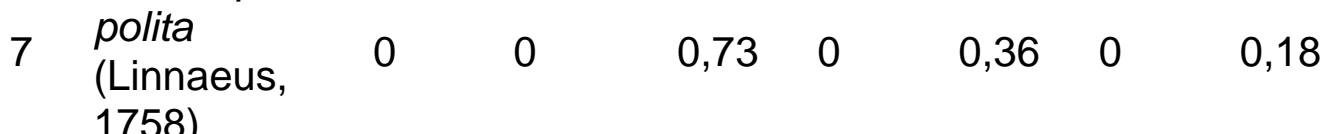
1758)

Pictoneritina

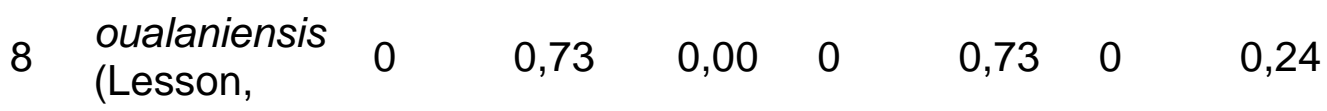
1831)

Planaxidae
Planaxis
9 sulcatus
(Born, 1778)
0
0
$\begin{array}{ll}27,2 & 0\end{array}$
5,45
$6,91 \quad 6,60$ 


\section{Muricidae}

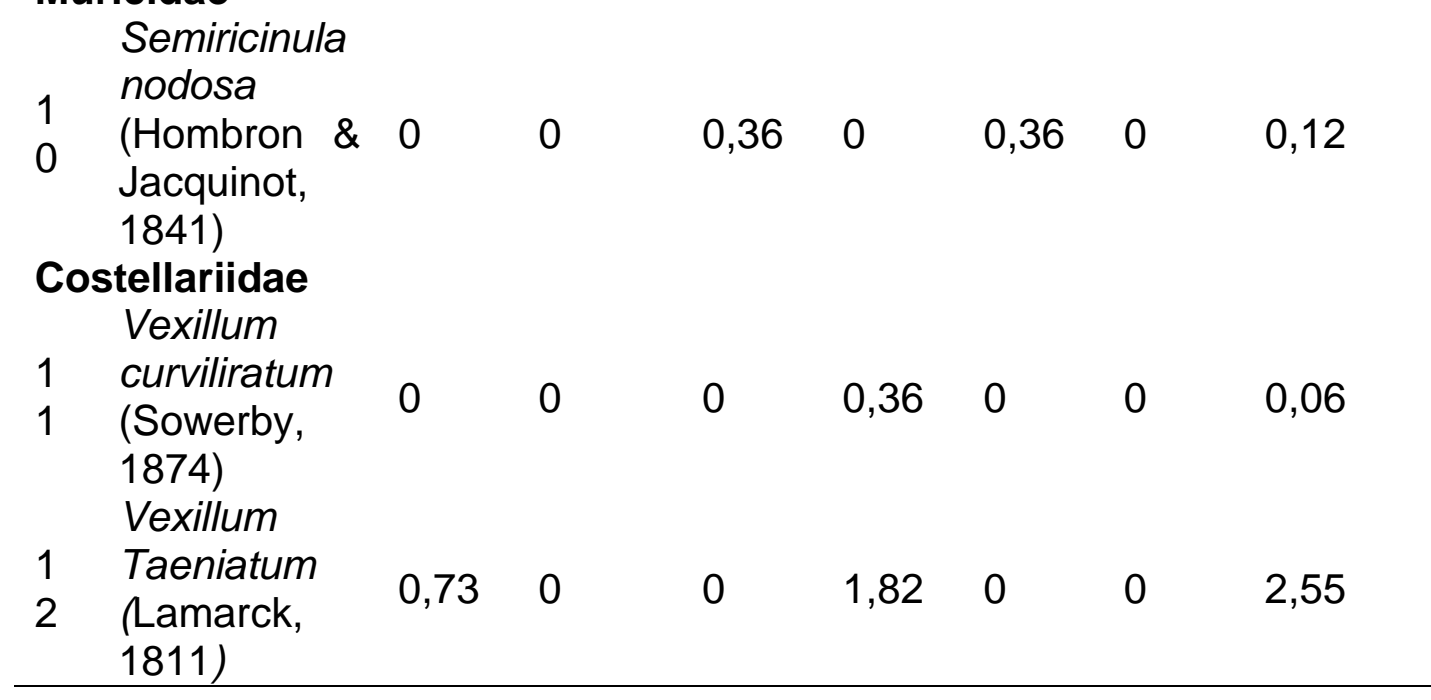

\section{Indeks Keanekaragaman, Keseragaman dan Dominansi}

Hasil perhitungan indeks keanekaragaman gastropoda disemua lokasi penelitian dikategorikan keanekaragaman kecil, dikarenakan nilai indeks keanekaragaman <2 (Odum, 1971) (Gambar 2). Ditinjau dari lokasi atau stasiun penelitian indeks keanekragaman rendah terdapat di stasiun 1, stasiun 2 dan stasiun 4. Rendahnya indeks keanekagaragaman dilokasi ini disebabkan oleh ekstrimnya kondisi lingkungan sehingga gastropoda yang hidup di dominasi oleh spesies-spesies tertentu. Hal ini dapat dilihat hasil perhitungan indeks dominansi pada stasiun 1,2 dam 4 di kategorikan tinggi dengan nilai berkisar 0,75 sampai 1 (Odum, 1971). Tingginya dominansi suatu spesies akan berpengaruh pada rendanhya kenekaragaman gastropoda di lokasi penelitian. Tingginya dominansi suatu spesies dapat disebabkan oleh beberapa faktor seperti kondisi habitat tercemar sehingga yang mampu hidup di habitat tersebut hanya spesies-spesies yang toleran terhadap bahan pencemaran atau ketersediaan sumber makanan yang melimpah untuk spesies-spesies tertentu, sehingga spesies yang lain tidak mampu berkompetisi.

Pada stasiun 1 (Pantai Tanjung Gunung) dan Stasiun 2 (Pantai Batu Betumpang) merupakan daerah pertambangan timah laut atau $\mathrm{TI}$ Apung di sekitaran wilayah pesisir perairan ini. Sedangkan untuk stasiun 4 merupakan daerah aliran sungai baturusa dan ada aktifitas pembuangan limbah dari pelabuhan dan PLTU air anyir (Tabel 1). Menurut Rachmawaty (2011) keanekaragaman spesies disuatu area dipengaruhi oleh beberapa faktor yaitu substrat yang tercemar, ketersediaan sumber makanan, kompetisi antar dan intra spesies, gangguan dan kondisi dari lingkungan sekitarnya sehingga jenis-jenis yang mempunyai daya toleransi yang tinggi akan semakin bertambah sedangkan yang memiliki daya toleransi yang rendah akan semakin menurun. Kondisi ini pada stasiun 1, 2 dan 4 di dominansi oleh genus Cerithidea sp, sehingga rendahnya 
keanekaragaman dilokasi ini. Selain itu pada stasiun 1, 2 dan 4 nilai dominansi paling tinggi.

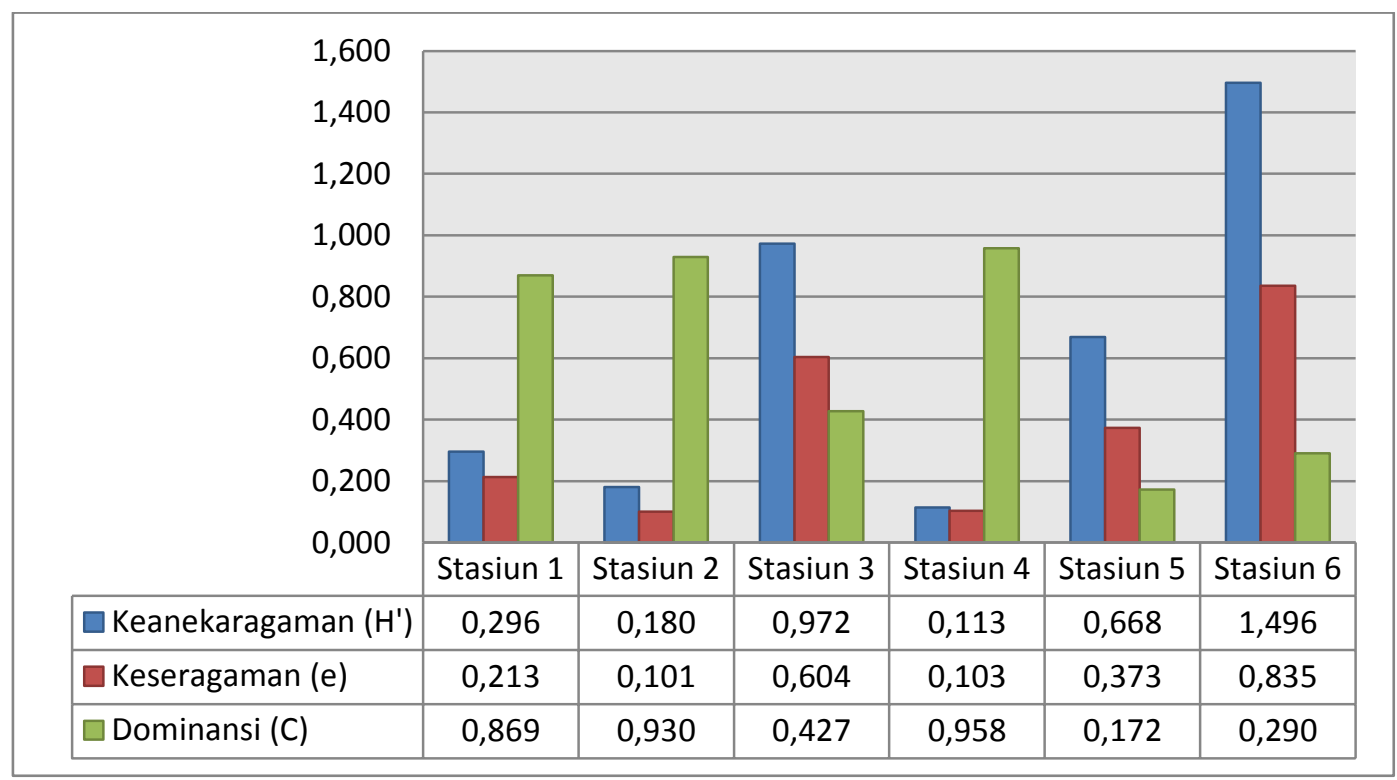

Gambar 2. Nilai Keanekaragaman, Keseragaman dan Dominansi Gastropoda

\section{KESIMPULAN}

Hasil penelitian ini ditemukan sebanyak 12 spesies gastropoda dari 8 famili. Famili yang ditemukan yaitu Cerithideidae (2 spesies), Cerithiidae (1 spesies), Cirridae (1 spesies), Nassariidae (2 spesies), Neritidae (2 spesies), Planaxidae (1 spesies), Muricidae (1 Spesies) dan Costellariidae (2 Spesies). Kelimpahan gastropoda yang tertinggi yaitu spesies Certhidea cingulata dengan kelimpahan rata-rata $124,54 \mathrm{ind} / \mathrm{m}^{2}$. Adapun nilai indeks keanekaragaman gastropoda di Pulau Bangka bagian timur dikategorikan kecil, hal ini diduga disebabkan oleh kerusakan habitat akibat dari aktifitas pertambangan di laut.

\section{UCAPAN TERIMAKASIH}

Penulis banyak berterimakasih kepada Universitas Bangka Belitung yang telah meyediakan dana dalam program Penelitian Dosen Tingkat Jurusan (PDTJ), sehingga penelitian ini bisa dilaksanakan. Selain itu penulis juga berterimakasih kepada pihak Jurusan Manajemen Sumberdaya Perairan dan Laboratorium Manajemen Sumberdaya Perairan yang telah banyak membantu dalam bentuk sumbangan pikiran dan tenaga sampai penelitian ini terlaksana. 


\section{DAFTAR PUSTAKA}

Brower., Zar, J.H., and Von Ende, C.N. 1998. Field and Laboratory Methodes for General Ecology. 4rd Ed. McGraw-Hill. United States of America

Dharma, B . 1988. Indonesian Shells . Jakarta : Sarana Graha

Febrianto A. dan Kurniawan. 2014. Pengaruh Logam Berat Pb Limbah Aktifitas Penambangan Timah Terhadap Kualitas Air Laut di Wilayah Penangkapan Cumi-Cumi Kabupaten Bangka Selatan. AKUATIKJurnal Sumberdaya Perairan. 8 (2) : 24-33

Irma D dan Sofyatuddin K. 2012. Diversity of Gastropods and Bivalves in mangrove ecosystem rehabilitation areas in Aceh Besar and Banda Aceh districts, Indonesia. AACL Bioflux. 5(2). 55-59

Krebs, C.J. 1998. Ecological Methodelogy. 2rd Ed, Addison-Welsey Education Publishers, California

Muslih K., Adiwilaga EM., dan Adiwibowo S. 2014; Pengaruh Penambangan Timah Terhadap Keanekaragaman Ikan Sungai Dan Kearifan Lokal Masyarakat Di Kabupaten Bangka. Limnotek. 21(1) : 52-63

Nurtjahya E., Franklin J, Umroh and Agustina F. 2017. The Impact of tin mining in Bangka Belitung and its reclamation studies. MATEC Web of Conferences. 1-6.

Nybakken, j. W. 1988. Biologi Laut. Suatu Pendekatan Ekologis. Jakarta: Gramedia

Odum, 1971. Fundamental of Ecology. Sounders College Publishing. Philadelphia.

Poutiers J. 1998. Gastropods In : The Living Marine Resources of the Western Central Pacific, FAO, Rome

Rachmawaty. 2011. Indeks Keanekaragaman Makrozoobentos Sebagai Bioindikator Tingkat Pencemaran Di Muara Sungai Jeneberang. Jurnal Bionature. 12 (2): 103 - 109

Silaen I.F., Hendrarto B dan Supardjo MN. 2013. Distribusi dan Kelimpahan Gastropoda pada Hutan Mangrove Teluk Awur Jepara. Journal Of Management Of Aquatic Resources. 2 (3) : 93-103

Suwignyo S., Widigdo B., Wardiatno Y., Krisanti M. 2005. Avertebrata Air Jilid 1. Penebar Swadaya. Jakarta 
Wahyudi R.A, Purnomo T dan Ambarwati R. 2014. Kadar Timbal (Pb) dan Kepadatan Populasi Cerithidea sp. di Pantai Selatan Kabupaten Bangkalan Madura, Jawa Timur. LenteraBio. 4(3). 174-179

Wahyuni H., Sasongko S.B dan Sasongko D.P. 2013. Kandungan Logam Berat pada Air, Sedimen dan Plankton di Daerah Penambangan Masyarakat Desa Batu Belubang Kabupaten Bangka Tengah. Prosiding Seminar Nasional Pengelolaan Sumberdaya Alam dan Lingkungan. 489-494 